\title{
AN EXAMINATION OF RECENT FEDERAL GOVERNMENT PROPOSALS TO REFORM THE SENATE OF AUSTRALIA VIA LEGISLATIVE AND CONSTITUTIONAL MEANS
}

\section{By Javier Rodriguez}

\section{Abstract}

Ce texte explique le besoin de réformer le Sénat de l'Australie. Il décrit premièrement deux suggestions faites par des membres concurrents du présent gouvernement de coalition pour rééquilibrer l'énorme pouvoir du Sénat. Par la suite, en énumérant les obstacles qui interdisent l'implémentation de chacune des deux suggestions, l'auteur suggère laquelle est le moins restrictive, ayant des exigences plus atteignables.

\section{Introduction}

Frustrated and dissatisfied with the legislative process, Australia's Coalition Government has floated a number of proposals for Senate reform. Its most recent suggestions are contained in two documents: Senator Helen Coonan's paper of 1999 'The Senate: Safeguard or handbrake on democracy?' ('Safeguard'), and the more recent discussion paper produced by the Prime Minister's Department, namely Resolving Deadlocks: A discussion paper on section 57 of the Australian Constitution (2003). 
There are two broad approaches one can take in the pursuit of Senate reform: legislative and constitutional. Coonan's paper takes the legislative approach, and suggests amending the electoral laws that govern how Australian Senators are elected, so as to increase the governing party's majority in the upper chamber. Resolving Deadlocks, on the other hand, provides an example of a constitutional approach to Senate reform. Alternatively, this article focuses on eliminating the deadlock-breaking position, found in section 57 of the Constitution, which requires that both Houses of Parliament be dissolved when such a situation arises.

Though neither of the proposals actually changes the institutional structure of the Australian Senate as such, it is clear that both intend to minimize its position in relation to the governing majority in the House of Representatives. Both articles are clear in their assertion that the Australian government is presented with a challenge when it does not retain a clear majority in the upper house, a situation that gives rise to Senate 'obstructionism'; a problem which they deem fundamentally distorting to the operation of Australian democracy. In other words, 'Safeguard' and Resolving Deadlocks are both articles that discuss what is considered to be a malfunction in Australian legislative government caused by an upper house operating from without the boundaries it was intended, and also provide a series of possible remedies for its correction. Irrespective of the side one takes with respect to the role and conduct of the Senate, the outcome, should either of the proposals examined in this paper become a reality, would result in either the governing party enjoying a numerical advantage in the Senate or in constitutional procedures granting them final say in disputes. In effect, either of the amendments would result in the executive government attaining an ascendancy over the legislature and the process of law-making, ultimately prevailing in legislative disagreements.

This paper first considers the rationale behind the proposals for Senate reform discussed in 'Safeguard' and Resolving Deadlocks. In addition to considering the impact of Australia's executive government receiving such legislative supremacy, this essay also considers the impact that the proposed reforms - particularly those contained in 'Safeguard' - are likely to have upon functioning of the Senate's committee system; an issue that becomes particularly crucial when one considers the valuable role the Senate plays with regards to 
holding the executive to account through their investigations of government action, the minute details of bills and so on. Next follows a critical examination of the preferred ${ }^{1}$ remedies outlined in each of these documents. And finally, this paper suggests that neither of the aforementioned remedies ideally address the need to strengthen Australia's Federal Parliamentary system, as they both fail to suggest amendments that adequately ensure the government will be held accountable. In effect, this paper concludes that if reluctantly forced to choose between each of the proposed solutions to this Senate 'obstructionism', it would be in the best interest of Australian democracy to adopt the solution proposed in Resolving Deadlocks - the amendment of section 57 of the Constitution.

From the Government's perspective, the key problem with Australia's legislative system is that it is unable to secure the passage of bills considered critical to its agenda through Parliament. In other words, the Government argues that the enactment of policies is being frustrated by the upper house, with damaging consequences to the country; a point which Coonan asserts with references to both the Government's failure to fully privatise Telstra, and exempt small business from unfair dismissal laws, as well as through the staggering figures he quotes, indicating the huge financial loss - of up to $\$ 40$ billion Australia has faced as a result of the upper house's intransigent approach to the Government's Native Title Act amendments. ${ }^{1}$ Even more alarming, is the point Coonan makes with respect to how the Australian Senate has hampered swift government action in response to the unforeseen unfolding of events. ${ }^{2}$ Resolving Deadlocks, on the other hand, does not evoke the same sense of urgency as Coonan's paper, but the central message is just as clear: a government majority in the lower house is licensed to govern subject to criticism and even minor delay, but no more. Both documents therefore criticize Senate 'obstructionism' by pointing to the government's legislative superiority, arguing in favour of amendments which secure the lower house's pre-eminence over the upper house.

The question of pre-eminence is complicated even further when one considers the fact that the current Australian government does not hold a majority in the upper house, leaving all potential government legislation at the 
mercy of non-Government Senators, rendering the Senate 'dysfunctional'. (Coonan 1999: 1), and leaving some to suggest that a "minority has [in fact] assumed a permanent and absolute veto over the majority." From the government's perspective, a functional Senate could thus be summarised as one where its bills are agreed to with little need for amendment or delay; a situation which prevents non-governmental institutions from disrupting or tampering with the machinery of government. In all fairness, however, such a situation must also be described as less than ideal, since such framework can only be arrived at through a self-serving and improper reading of the written Constitution; a reading which diminishes and misrepresents the effective power minor parties and independents wield in the Senate. Nowhere in Australia's Constitution does it suggest that the Senate is required to obsequiously pass bills sponsored by the majority in the lower house. On the contrary, section 53 - in conjunction with section 57 - of the Constitution suggests that all bills must receive the approval of both Houses of Parliament before they can become law. It was the intention of the founders of the Constitution that all bills would require the approval of both Houses of Parliament before they could be presented for royal assent. ${ }^{5}$

It thus becomes unfair to suggest that the Senate is 'dysfunctional' simply because it refuses to grant its consent whenever a government demands it. Then again, so too is it nonsense to argue that Senate minorities exercise an 'absolute veto over the majority', effectively handing minor parties and independents a 'casting vote, ${ }^{, 6}$ as Australia's political history is littered with instances where compromises have been in order to secure the passage of legislation. For instance, the Howard Government successfully negotiated the partial sale of Telstra with one independent Senator ${ }^{7}$ and the introduction of the Goods and Services Tax with the Australian Democrats, two key areas of their policy platform. Similarly, the Keating Labor government was forced into making concessions with its 1993 budget with minor parties given that the, then, Liberal Party Opposition vowed to block it in the Senate. ${ }^{8}$ These examples of compromise between the two houses of parliament thus render assertions that the 'minority has an absolute veto over the majority' inaccurate. Rather, Government negotiations to find supporters for their bills has become a 'mix and match' game in which the only objective is get its policies through the chamber, no matter who supports it. ${ }^{10}$ As Ramsey explains, minor parties and independents do not hold the 'balance of power', rather they 'share it' with the 
twenty-eight Labor Senators. $^{9}$

Despite the fact that it becomes absurd to suggest that the Senate does not somehow operate in accordance with its constitutional powers, this is the effective position expounded in both 'Safeguard' and Resolving Deadlocks. In each of these articles, the pre-eminence of the House of Representatives in legislative matters is presented, arguably, in the context of the conventions of responsible government expounded with brevity and in a simplistic manner - a fashion that is incompatible with Australia's federal system of government. Concomitantly, the Senate is portrayed as a near-defunct institution, which operates contrary to the founders' intentions; that is, as a states' house which functions in order to defend states' interests. Such an impression of the Senate therefore contributes to the notion that it has little to no legitimate role to play in legislative matters, unless issues are resolved in the government's favour, or constitutional mechanisms are redressed to ensure the lower house can prevail without resort to section 57 as it currently stands.

Resolving Deadlocks begins by presenting Australia's Parliamentary system in the context usually applied to other, Westminster-derived, bicameral institutions: $:^{11}$ the lower house acts as the 'popular house' in contrast to the upper house, or the 'house of review', whose function stretches beyond 'review' and the expression of a second opinion with respect to prospective legislation towards the representation of individual states in the national legislature. Nevertheless, this particular article also argues, that since its inception, the Senate has lost its way and been held captive to those who occupy it, namely parties - a situation that has only been exacerbated with the increasing presence of minor parties - and, as a result, no longer operates as a states' house. ${ }^{12}$ Similarly, Coonan's paper is littered with assertions that the Senate no longer operates as a states' house and instead has been hijacked by political parties pursuing their own interests. As a result, Coonan as concludes that the Senate functions contrary to the founders' intentions: that is, in exercising "co-equal powers within a system of responsible government."13 
These two arguments regarding the intended role of the Senate and the place of responsible government in Australia's constitutional system, which buttress the Government's case for Senate reform, are thus comprised of incomplete assessments of the founders' intentions and a glossing over of the federalist principles contained in the Constitution. Given that the Government's case for reform rests in large part on the place of responsible government, it is perhaps surprising that neither 'Safeguard' nor Resolving Deadlocks contains any clear explanation of what that system of government actually means - with the exception of offering a simplistic explanation of how majorities in the lower house are given the right to govern. Interestingly, at the time of drafting the Constitution in the late $19^{\text {th }}$ Century, there were numerous variations on the doctrine of responsible government, as the founders of the Constitution were aware that there was no precise or singular meaning, especially since it was undergoing a process of change. ${ }^{14}$ Popular among the founders, however, was J. S. Mill's conception of responsible government and the functions of legislatures, which, apart from advancing a strong position on the power of parliament to make or break ministries, also included a defence of second chambers for the purposes of countering the majority in lower house that may lack a compulsion to respect minority interests. ${ }^{15}$ So too was Dicey's emphasis, moreover, on the role of parties in the system of responsible government popular among the Constitution's founders. ${ }^{16}$ Nevertheless, responsible government in general, and its adaptation to federalism in particular, was viewed with a great deal of scepticism by a significant number of those involved in the making of the Constitution. ${ }^{17}$

From the first Convention Debate in 1891, three main positions emerged with respect to the form the federal scheme should operate under: (a) either with the establishment of responsible government and a weaker upper house; (b) the rejection of responsible government and the adoption of a powerful upper house; or, the prevailing position, (c) an amalgamation of the first two positions which, despite the theoretical differences between them, entrusts the people of Australia to ensure that the new nation would not tear itself apart. ${ }^{18}$ The constitutional solution is to be found in section 53 of the Constitution, where the difference in powers between the two Houses is of the slimmest margin. The Westminster system of responsible government is thus, as Davis puts it, almost 'irrelevant' in understanding Australia's bicameral structure, especially since the Senate, unlike 
the House of Lords, is fully elected and thus enjoys full democratic legitimacy, and since Parliament is not sovereign, as its powers remain prescribed under sections 51 and 52 of the Constitution. ${ }^{19}$ At the very least, then, all the doctrine of responsible government informs us of in Australia's political system is the basic notion that government is formed by the party(ies) which command a majority of seats in the lower house and whose ministers direct departments of state for which they are answerable to Parliament.

The absence of a Westminster system of responsible government in Australia has led observers to argue that either responsible government does not really exist in Australia, or that it operates in a context where government is responsible to both Houses of Parliament. The central aspect of this reasoning is that tight party discipline has meant effective government accountability can only be assured by through the check provided by a non-government majority in the upper house, ${ }^{20}$ which renders the cabinet also directly responsible to the Senate. $^{21}$

Accurate as it may be that the Senate was, for the most part, intended to represent states' interests, the Government - like many critics of the Senate overlook the subtleties in the arguments put forth during the federation debates regarding the manner in which the Senate would operate and just who it would represent. Contained in some of those arguments is the recognition of the likelihood that competing parliamentary members' allegiances would eventually rest with their party colleagues rather than with the states in which they reside. ${ }^{22}$ That being said, it makes little sense to maintain the view that the Senate is exclusively a states' house because states have little to play, either directly or indirectly, in the composition of the Senate, ${ }^{23}$ and certainly no power to influence its deliberations. In short, the Senate does not represent the states, in as much as that term carries with it the suggestion that their local and distinct political institutions or figures are somehow involved, present or indeed even consulted in the federal legislature. Rather, the Senate represents the people of each of the states ${ }^{24}$ whose interests and convictions could be shared with the people of other states. It was partly for this reason that the framers of the 
Constitution decided to change the original name of the upper house from 'States' Assembly' to Senate.

In recognition of its federalist role, the Australian Senate, like its American counterpart, is designed to ensure that the majorities formed within it during its deliberations on proposed laws would be geographically distributed, meaning that a majority of Senators from a majority of states would comprise the overall majority in the chamber. ${ }^{26}$ Here the principle of equal representation in the Senate of each original state, despite differences in population sizes between them, is important because it ensures that the people from the more populous states, whose representatives outnumber all others in the lower house, cannot dominate the entire legislative process. ${ }^{27}$ Equal representation in the Senate thus prevents a would-be power Senate from "convert[ing] the popular will...into the federal will." ${ }^{28}$ The composition of Australia's Senate also reflects the understanding held by some of the founders that the Senate's key role, as part of a national bicameral structure, would be in shaping national policy and legislation, rather than simply acting as a 'watchdog' for central government. ${ }^{29}$ In other words, the purpose of electing the Senate is to decide which parties should govern and determine federal policy more so than who should protect the interests of the states in particular.

It is thus against this fundamental set of errors, regarding the role and functions of the Senate and the place of executive government within the Australian bicameral system, that the Federal Government asserts its unfounded legislative supremacy. However, given that opposition and minor parties in the Senate frustrate such assumed powers, the Government has concluded that the upper house ought to be reformed. As is indicated in the introduction of this paper, there are only two approaches one can take in the pursuit of such reform: legislative and constitutional. Two of the Government's most recent proposals involve these two methods, though neither directly tampers with the Senate's actual powers. Nevertheless, each of these proposals clearly identifies that the Government's objective is to mitigate the Senate's ability to enforce amendments upon government-sponsored bills, indeed rendering the Senate's effective power an indirect casualty.

The first proposal to reform the upper house analysed here involves having to amend statutory law so as to increase the likelihood of greater governing party 
membership in the Senate at the expense of minor parties and independents. ${ }^{30}$ It is with this proposal that the Senate's committee system faces the greatest danger. Alternatively, the second proposal, as outlined in Resolving Deadlocks, involves the constitutional method of reform.

Both Coonan (1999) and Resolving Deadlocks (2003) identify the 1949 use of proportional representation (PR) for upper house elections and the 1984 expansion of the Senate from 60-76 members as having cemented the place of minor parties and independents in the upper chamber. ${ }^{31}$ Coonan's proposed solution to this strong proportion of minor parties and independents in the Senate is the imposition of a minimum threshold on the number or primary votes a candidate must receive before they could attract preferences. ${ }^{32}$ Under Coonan's system, preferences from those candidates which do not meet the threshold then would be distributed according to whichever means prescribed. ${ }^{33}$ Having said this, under the most stringent example provided by Coonan, where the minimum of $11.43 \%$ of primary votes would have been required, only four out of the total sixteen minor party and independent Senate candidates elected in the 1993, 1996 and 1998 elections would have received preference votes. In other words, with no party other than the Liberal Party (LP) and the Australian Labor Party (ALP) winning anywhere near that primary vote threshold in the states and Territories of NSW, Victoria, WA, Tasmania and the NT in the 1998 half Senate election, every other party from those electorates would have not received primary votes. $^{34}$ Moreover, with up to $41.14 \%$ and no less than $34.81 \%$ of the primary votes going to the major parties in some of the states and Territories in the 1998 half Senate election, Coonan's $11.43 \%$ threshold of primary votes would have, in some instances, been satisfied by the LP and ALP no less than three times over. ${ }^{35}$ Add to that the huge preference vote flow from candidates which did not meet the minimum threshold and the LP's and ALP's total vote count would certainly ensure an even greater number of members in the Senate.

The object of such reforms is thus clear: the near deletion of minor party and independent Senators. 'Safeguard' and Resolving Deadlocks are thus correct in their conclusion that the introduction of PR and the expansion of the Senate has contributed to the loss of major party control of the upper house. However, they overlook or argue away the fact that part of this loss of major party control also stems from the gradual decline in their primary vote and from the fact that 
electors are increasingly voting differently in the Senate compared to that of the House. ${ }^{36}$ Coonan almost expresses lament at the fact that in order to win a majority of seats in a state in a half-Senate election - that is, four out of six seats - her party would have to win four quotas, or $57.12 \%$ of the vote for that state; in other words little more than half the total vote in only four of the states and one Territory in order to secure an overall upper house majority. It is difficult to sympathise with Coonan's proposed dilemma considering that such a percentage also does not constitute even a mere two-thirds of the total vote. The questions to be asked therefore are: (1) should a government, in a context where tight discipline is maintained over Parliamentary parties, expect to attain full legislative control without even having secured two-thirds of the total vote; and, (2) is it right to award a party that wins not much more than half the total vote complete control over the legislative power? Rather than concentrating on the obvious arguments that could be made regarding the undemocratic nature of such reforms, since they severely limit the diversity of opinion and effective electoral choice available to voters, this paper will instead pay particular attention to the impact that such reforms would have on the Senate's system of committees.

The potential fate - that is, dilution and undermining - of the Senate's committee system under Coonan's proposals are best illustrated by looking at the Senate in its modern form, that is, without a government majority in the upper house. The genesis of this modern Senate committee system is the result of the efforts made by the (then) Clerk of the Senate, as well as the ALP Opposition Leader in the Senate, Lionel Murphy, in establishing a committee structure similar to that operating in the American Senate and the British Parliament. ${ }^{38}$ This modern Senate committee system was then refined in 1970, with the establishment of seven legislative and general purpose standing committees, which were to examine a range of issues in detail, from bills to the areas which they each cover, and in 1994, with even further refinement which specifically helped revitalise the Parliamentary process of scrutinising proposed laws, and, more generally, enhanced the legislature's ability to hold the executive to account. $^{39}$ Under the 1994 reforms, membership in the Senate's eight pairs of Reference and Legislation committees and their Chairs is designed to reflect the overall composition of the Senate. ${ }^{40}$ With Senator Coonan's proposed reforms, however, the 1994 rationale for the allocation of positions on standing committees and their chairs would either no longer apply, or would reflect the much enhanced majority party presence in the chamber. Furthermore, the effectiveness and establishment of Senate Select Committees, if proposed by non-government Senators, would also be under threat. Select Committees, unlike 
standing committees which are semi-permanent and established by the Senate's Standing Orders, are established by a motion outlining its terms of reference, membership (and therefore party composition) and time-frame in which to finalise its report. ${ }^{41}$ Simply put, the structure of Select Committees is such that they can only become operative if the Senate itself agrees to the motion that seeks to establish it, rendering the establishment of such committees of inquiry rather unlikely. ${ }^{42}$

The Government's preferred model of constitutional reform is outlined in Resolving Deadlocks. ${ }^{43}$ It involves the amendment of section 57 of the Constitution so as to permit the Prime Minister to advise the Governor-General following what is termed an 'ordinary' election - to convene a joint sitting of Parliament to consider a bill that has been 'blocked' twice in the previous parliament and once again in the new; ${ }^{44}$ a solution that prevents having to proceed in the manner currently prescribed - the dissolution of both houses of parliament, followed, if necessary, by a joint sitting. As with the current arrangements under section 57, the Resolving Deadlocks proposal requires that an interval of at least three months separate each occasion in which the bill failed to pass in the Senate of the previous Parliament. Also similar to the current form of section 57, this proposal does not insist that a minimum amount of time lapse between the Senate 'blocking' the disputed bill and the convening of a joint sitting in the new Parliament. In addition, since Australia currently has no fixed terms in the lower house, leaving elections up to the discretion of the Prime Minister - within the three year limit set by section 28 of the Constitution Resolving Deadlocks proposes that the timing of 'ordinary' elections 'depend on the time the deadlock arose.' Consequently, under the Resolving Deadlocks system, the Prime Minister would be able to stage a so-called 'ordinary' election for the lower house alone, and then convene a joint sitting shortly thereafter. In addition, since the quota needed to secure a seat in a full Senate election is halved from $14.28 \%$ of the vote to $7.7 \%$, which, incidentally, is much more unlikely to yield a Senate majority for the government than is a regular, halfSenate election. This second proposal thus dispenses with the difficulties of government having to risk dealing with an even more hostile Senate following a double dissolution of Parliament.

Consequently, it is thus not particularly surprising that both Resolving 
Deadlocks ${ }^{45}$ and 'Safeguard'46 emphasise the 'unworkability' and 'risk' involved when governments utilise section 57 as it currently stands; as what happens to the government's bills in the Senate subsequent to a double dissolution election would be of major concern to a government anxious to legislate the rest of its policy agenda.

Moreover, as Resolving Deadlocks points out, part of government reluctance to stage double dissolution elections also rests with the risk of losing. ${ }^{47}$ If this were the case, however, and a government that finds itself in such a position were to decide not to exercise section 57 of the Constitution, doubts would be raised as to the extent the government really considers its deadlocked bills a matter of urgency. Furthermore, if voters were to throw-out a government in a double dissolution election, it could only be assumed that it was their proclivity to not see the government's measures adopted by the Parliament and the issue thus properly resolved. Incidentally, the fact that the Government included such an argument in its case against the current constitutional arrangements evidently illustrates the extent to which self-interest conditions its assessment and desires to have provisions amended. Surely a government with strong convictions, a sense of purpose and a genuine belief in the goodness of the measures and merits of which it could not convince Parliament, would take the risk and seek an election, especially when the chamber in which they are stalled would also be subjected to the judgment of the people.

The other significant problem with the Resolving Deadlocks proposal is the de-synchronization of lower and upper house election once the House of Representatives is dissolved alone. Section 13 of the Constitution, which establishes the rotation of Senators, requires each Senate spot to be opened for re-election in the final year of their six year duration, thirty-six out of which (that is, half of the total number of Senators) are alternately elected every three years. Senators, therefore, unlike the members of the House, have a constitutionallybased, six year fixed term which cannot be truncated unless section 57 of the Constitution becomes operative. Thus, this second proposal for reform - which keeps the Prime Minister's discretion in calling a House election anytime within a three-year period intact - could forge a situation where shortly after having staged a deadlock-breaking lower house election, a half-Senate election would also have to be held. If the conditions brining this second proposal took place, and the subsequent lower house election was held one year into its original term, a lone half-Senate election would also have to be held within two years of the lower house's last dissolution. It thus becomes theoretically possible for there to 
be up to three federally-based elections within three years: the original lower house election, followed by an early lower house election, and again for the regular half-Senate election occurring every three years. Such staggering of lower house and half-Senate elections could thus only be corrected with yet another early lower house dissolution held in time with the next half Senate election. Alternatively, one could re-calibrate Parliamentary elections by dissolving both Houses of Parliament under section 57. Despite the fact that these aforementioned are subject to timing, and thus not problems that would not emerge as a matter of routine, this second proposal still has the overall effect of diluting the lower house's power to legislate independently of the executive, since a joint sitting of Parliament, followed by a much less-risky election, would provide the government with even less incentive to seek compromises with other parities on its policy enactments.

\section{Conclusion}

There are a number of points to be made. Both of the proposals examined here are likely to deliver to legislative ascendancy and Parliamentary control far greater than is presently the case. On the one hand, Coonan's imposition of a minimum threshold on the number/percentage of primary votes candidates must win before they receive preference votes would enable parties with a majority in the lower house to win a majority in the Senate as well. Nonetheless, there is no reasons to believe that this would always be the case, for such reforms are aimed, almost exclusively, at excluding - though perhaps not entirely - minor parties and independents, thereby rendering it much more likely that the main Opposition parties themselves win an upper house majority ${ }^{49}$ - a possibility that Coonan failed to address.

Leaving aside the dangers that suggested reforms may pose for governments, the prospect of executive control over the entire Parliament is not a particularly healthy one. Out of the forty-four national governments Australia has had from 1901-2001, nineteen also had Senate majorities. ${ }^{50}$ Governments in such a position would have little regard for other points of view and would not be compelled to accommodate differences of opinion. It was shown in the course of this paper that the highly acclaimed Senate committee system, accurately credited with revitalising Federal Parliament and largely responsible 
for the bulk of the work put into analysing government activities, would not have emerged were it not for effective government minorities in the founding chamber. Government majorities in the Senate would now, in all likelihood, undermine the upper house's committee system. The rationale behind the allocation of party membership and distribution of chairs to standing committees which has, since 1994, took into account the presence of minor parties and independents in the Senate, is unlikely to remain intact if the major parties were to dominate the upper house in greater numbers than they presently do. There can be no denying that non-Coalition or non-ALP influence in virtually all respects would be significantly diminished. Moreover, Senate Select Committees also stand to be weakened should the executive assume control over the Senate, since these types of committees are only established by orders of the Senate and carried by a majority of votes within the chamber. Thus, if the government were to control the upper house, Opposition efforts to compose an inquiry into any particular matter the government does not want investigated could be easily defeated. Having said this, Coonan's proposal would be far easier to realise than this second one, for the simple reason it requires an amendment to statutory law, a process which necessitates a majority vote in of both Houses of Parliament. Because any prospective governing party could stand to benefit from any measure, which seeks to erode the number of minor party and independent Senators, it is not totally improbable that the main Opposition party agree such amendments.

On the other hand, the second proposal for reform is much more ambitious as it requires a referendum for constitutional amendment. Hypothetically, if such an amendment were to succeed, despite the fact that constitutional change in Australia via the referendum process is extremely difficult and almost a lost cause, it would no doubt provide any government with the ultimate power over the fate of bills - provided they win the ensuing election. Because of the inherent time constraints involved with the adoption of this second proposal especially in comparison to Coonan's proposal where there is virtually no time constraint should the government attain an upper house majority - such an option would at least provide the opportunity for a more condensed, and thus intense, deliberative process. Although the three-month minimum interval between the Senate's rejection of a bill in one Parliament, followed by an election presumably focused on the bill provoking the poll, would to some degree enable considerable public debate on the issues involved, the reality is that the second proposal is more favourable; it provides for a single dissolution of Parliament rather than a double dissolution since under this scheme, the Prime Minister may hold a lower or upper house election alone, which is, no doubt, one 
of the objects of such a reform. Resolving Deadlocks made it abundantly clear that section 57 in its current form was 'unworkable' and too risky for governments to contemplate. The 'risk' of a double dissolution election is that whilst it would enable a government to pass its deadlocked bills through a joint sitting, the new Parliament, in particular the new Senate, elected with a reduced quota and providing therefore for a further enlarged cross-bench, would cast considerable doubt over the fate of the government's subsequent legislative programme. This is why double dissolution elections are dangerous for governments, especially at present when major party primary votes are on the decline, as well as the reasons why this second proposal, with its single dissolution alternative, is considered the preferable proposal in the eyes of the government.

The biggest problem with Option Two, second to potentially providing the government with near-total legislative control, is the subsequent series of staggered elections - one for the House and one for half of the Senate, corrected only by further early dissolutions of the lower house - that would arise once a Prime Minister chose to stage a lower house election alone, as was discussed earlier in the paper. Option Two thus potentially provides for a decidedly untidy system of government should a confident and obdurate Prime Minister ever assume office. It should thus be clear that although more favourable that Coonan's proposal, this second proposal does not enhance Australia's system of government. The final point to be made is that out of the two proposals explored in this paper, Coonan's, the one which emerged as the worst and arguably most dangerous to the maintenance real legislative government greatly more separated from the executive, also happens to involve the easiest method of activating.

\section{ENDNOTES}

${ }^{1}$ Safeguard', like Resolving Deadlocks, canvases numerous proposals for Senate reform. This essay will examine only those that were advanced as the preferred options. Hence, only Coonan's preferred model, contained within the pages 24-6 of her paper, involving the imposition of a threshold on the percentage of primary votes won by a Senate candidate before preference votes can be distributed to them, is subject to analysis in this essay. Similarly, only Option 
Two, the Government's preferred option of those canvassed in Resolving Deadlocks, is examined in this essay.

${ }^{2}$ Coonan 4-6.

${ }^{3}$ Ibid. 6.

${ }^{4}$ Ibid. 1.

${ }^{5}$ Resolving deadlocks 6.

${ }^{6}$ Galligan 63-90; Evans, Odgers 2; Bach 131; Bennet 4-5.

${ }^{7}$ Coonan 3 and 19-20.

${ }^{8}$ Singleton and Aiken, et al. 150.

${ }^{9}$ Incidentally, the public response to Resolving Deadlocks, recorded at very poorly attended public meetings held around the country and reported on by the Consultative Group on Constitutional Change, established by the Government to educate the public and stimulate debate on the issue, noted that in some instances, '( $t$ )he atmosphere at some of the public meetings...bordered on hostile..' to the Government's motives in general and that '(m)any took... issue...' with the discussion paper's assertion regarding minor parties exercising 'absolute veto' powers over bills (Consultative Group on Constitutional Change 35-6).

${ }^{10}$ Ramsey 39. In fact, as point out by Ramsey in his article, Tasmanian Independent Senator Brian Harradine also supported the bill; but with thirty-five Government and twenty-eight Opposition Senators voting for the bill, Harradine's support counted little and was inconsequential.

${ }^{11}$ Ibid 39.

${ }^{12}$ Resolving Deadlocks 9-10. 
${ }^{13}$ Ibid.13-14.

${ }^{14}$ Coonan 3.

${ }^{15}$ Uhr 58-9.

${ }^{16}$ Ibid. $72-4$.

${ }^{17}$ Ibid. 77.

${ }^{18}$ Ibid. $79-80$.

${ }^{19}$ Bach 121; Galligan 85-6.

${ }^{20}$ Davis $97-8$.

${ }^{21}$ Evans, Accountability 4; Evans, Acountability 9; Mulgan.

${ }^{22}$ Galligan 63-90; Senate Brief no.10 1-2; Davis 78-102.

${ }^{23}$ Evans, Odgers; Coonan 8; Bach 146-7.

${ }^{24}$ Except under the extraordinary circumstances outlined under section 15 of the Constitution, where vacancies in the Senate can be replaced by the parliament of the state from which the ex-Senator derived.

${ }^{25}$ Evans, Accountability 8-11; Evans, Odgers; Bach 142-5; Galligan 68-9; Fenna 83; Howard 70-3.

${ }^{26}$ Uhr 110.

${ }^{27}$ Evans, Odgers; Coonan 8.

${ }^{28}$ Ibid. Thus, the legislative process is similar to the mechanism which decides 
the outcome of referenda, as stipulated under 128 of the Constitution: a proposal to amend the Constitution can only succeed if the 'yes' vote is carried by an overall national majority - as would a bill in the House of Representatives, representing the people as a whole - and a majority of the people in a majority of the States (4/6) - as would a bill in the Senate, representing the people of the states (Evans, Odgers).

${ }^{29}$ Davis 80.

${ }^{30}$ Galligan 67-9; Bennett 22.

${ }^{31}$ Coonan.

32 This system of voting involves the imposition of a quota, calculated by dividing the total number of formal votes cast by the number of Senators to be elected (six in a regular, half Senate election or twelve in a full, double dissolution election) plus one, and then adding one to the result (Australian Electoral Commission 54). Hence, if the total number of formal votes cast in a state for half Senate election was 700,000, the quota would be 100,001, the number of votes a candidate would need in order to secure a Senate spot (Senate Brief no.12). Moreover, the Senate electoral system includes a preferential system so that candidates, who do not reach a quota in primary votes alone, can still nevertheless attract enough preference votes distributed to them on the ballot paper in order to win a seat in the upper house (Senate Brief no.1 2-3). The effect of expanding the number of Senators is the increase the number of candidates per state, which drives down the quota needed to secure a place in the Senate.

\section{${ }^{33}$ Coonan.}

${ }^{34}$ That is, if a voter votes 'above the line,' preferences would be distributed to those in a manner decided by the party the elector voted for. If an elector votes 'below the line,' preferences would be distributed according to how they appear o the ballot paper.

${ }^{35}$ For 1998 Senate election results see, The Australia Electoral Commission 78- 
82.

${ }^{36}$ The Australian Electoral Commission 78-82.

${ }^{37}$ Solomon 91; Bach 48; Coonan 17.

${ }^{38}$ Coonan 13.

${ }^{39}$ Solomon 80-4.

${ }^{40}$ Evans; Smith 124-9; Reid \& Forrest 40-88.

${ }^{41}$ Evans, Accountability 347-8; Senate Brief no.4 4.

${ }^{42}$ Senate Brief no.4 2; Brief Guides to Senate Procedure no.6.

${ }^{43}$ Bach 189-90; Weller 45. It is also interesting to note that Senate Select Committees composed entirely of one party is not without precedent either; a 1950 Senate Select Committee, charged with the responsibility to inquire into the provisions of section 57 of the Constitution, comprised Labour Opposition members only because Government Senators refused to participate (Crisp 344). Unlike with standing committees, there are no rules that compel the Senate to include any particular Senator from any particular party in the composition of such a committee. It would therefore be open to a governing party that controls the Senate to establish such a committee composed entirely of government Senators. It would be relatively safe to assume that such a committee so composed would not function to probe into activities the government does not want to be made public, but rather for some other, highly partisan issue.

\section{${ }^{44}$ Resolving Deadlocks 32.}

${ }^{45}$ This second proposal for reform, moreover, would not eliminate double dissolution elections from the Prime Minister's options; she or he could chose between the current arrangement as they exist in section 57, or seek a joint sitting following a general election to consider bills blocked by the preceding 
parliament (Resolving Deadlocks 42-3).

${ }^{46}$ Resolving Deadlocks 25, 32, 34-5.

47 'Safeguard' 9, 21-3.

${ }^{48}$ Resolving Deadlocks 32.

${ }^{49}$ Resolving Deadlocks 42-3; Brown 69.

${ }^{50}$ Green 47.

${ }^{51}$ Bach 50.

\section{Bibliography}

Australia. "Committee Membership: Brief Guides to Senate Procedure No. 6." Canberra: Department of the Senate, 2003.

Australia. Australian Electoral Commission. Electoral Pocket Book. Canberra: AEC, 1999.

Australia. Constitutional Change, Legal and Culture Branch. Resolving Deadlocks: A discussion paper on section 57 of the constitution. Canberra: Department of the Prime Minister and Cabinet, 2003.

Australia. Department of the Senate. "Electing Australia's Senators." Senate Brief No. 1. Canberra: Department of the Senate, 1999.

Australia. Department of the Senate. "Senate Committees." Senate Brief No. 4. 
Canberra: Department of the Senate, 2002.

Australia. Department of the Senate. "The Role of the Senate." Senate Brief No. 10. Canberra: Department of the Senate, 1999.

Bach, S. Parliament of Australia. Platypus and Parliament: The Australian Senate in theory and practice. Canberra: Department of the Senate, 2003.

Bennett, S. Australia. Information and Research Services, Parliamentary Library. "The Australian Senate": Research Paper No. 6 2003-4.' Canberra: Department of Parliamentary Services, 2004.

Brett, J., J. Gillespie, and M. Goot, eds. Developments in Australian Politics. South Melbourne: Macmillan Education Australia, 1994.

Brown, N. A. Australia. Constitutional Change and Legal Branch. Consultative Group on Constitutional Change. Resolving Deadlocks: The public response. Canberra: Department of the Prime Minister and Cabinet, 2004.

Coonan, H. "The Senate: Safeguard or Handbrake on Democracy?" Address to the Sydney Institute, 3 February 1999.

Crisp, L. F. Australian National Government. Croydon: Longman Australia, 1970.

Davis, S. R. Theory and Reality: Federal ideas in Australia, England and Europe. St. Lucia: Queensland of University Press, 1995.

Evans, H. Australia. "Accountability Versus Government Control: the effect of proportional representation." Papers on Parliament No. 34 - Representational and Institutional Change: 50 years of proportional representation in the Senate. Canberra: Australian Governments Publishing Service, 1999. 
Evans, H., ed. Odgers' Australian Senate Practice, $8^{\text {th }}$ ed. Canberra: Australian Government Publishing Service, 1997.

. "Federalism: An idea whose time has come?" Delivered at the Samuel Griffith Society Conference, 7-9 March, 1997.

Fenna, A. Essential of Australian Government. Croydon: Tertiary Press, 2001.

Galligan, B. A Federal Republic. Cambridge: Cambridge University Press, 1995.

Green, A. "Time to Review the House of Review." Sydney Morning Herald 11 September 1999: 47.

Howard, C. Australia's Constitution. Ringwood: Penguin Books, 1986.

Mulgan, R. "The Australian Senate as a "House of Review." Australian Journal of Political Science 2.1 (1996): 191-204.

Ramsey, A. "Told to heel, this dog's still got the bite." Sydney Morning Herald, 28-29 June 2003: 39.

Reid, G. S. and M. Forrest. Australia's Commonwealth Parliament: 1901-1988. Carlton, Melbourne University Press, 1989.

Singleton, G., D. Aitkin, B. Jinks \& J. Warhurst. Australian Political Institutions, $7^{\text {th }}$ ed. French Forrest : Pearson Education Australia, 2003.

Smith, R. "Parliament." Developments in Australian Politics. Eds. J. Brett and J. Gillespie et al. South Melbourne: Macmillan Education Australia, 1994. 106131. 
DOCUMENT TITLE

Solomon, D. The Coming of Age: Charter for a new Australia. St. Lucia: Queensland University Press, 1998.

. Inside the Australian Parliament, Sydney: George Allen \& Unwin, 1978.

Uhr, J. Deliberative Democracy in Australia: The changing place of parliament. Cambridge: Cambridge University Press, 1998.

Weller, P. Don't Tell the Prime Minister. Melbourne: Scribe Publications, 2002.

Young, L. "Minor Parties and the Legislative Process in the Australian Senate:

A study of the 1993 budget." Australian Journal of Political Science 34.1

(1999): 7-27. 